\title{
Morphology of the antennal sensilla of two species of Hoplopyga Thomson, 1880 (Coleoptera, Scarabaeidae, Cetoniinae)
}

\author{
Cleicimar Gomes Costaํㅜ Sérgio Roberto Rodrigues ${ }^{1 *}$ (D), Juares Fuhrmann²
}

${ }^{1}$ Universidade Estadual de Mato Grosso do Sul, Cassilândia, MS, Brasil.

${ }^{2}$ Universidade de São Paulo, Museu de Zoologia, São Paulo, SP, Brasil.

\section{A R T I C L E I N F O}

\section{Article history:}

Received 07 August 2020

Accepted 17 February 2021

Available online 22 March 2021

Associate Editor: Adriana Marvaldi

\section{Keywords:}

Chemical communication

Gymnetini

Isoptera

Neotropical

Sexual dimorphism

\begin{abstract}
A B S T R A C T
Antennal sensilla are important functional elements of sensory systems in insects. This study aimed to determine the morphology and structure of the sensilla of two species of the genus Hoplopyga. Adults of Hoplopyga liturata (Olivier, 1789) were collected in traps with sugarcane juice as an attractant. Thereafter, larvae of Hoplopyga albiventris (Gory and Percheron, 1833) were collected in mounds of termites (Cornitermes cumulans (Kollar, 1832 ) Isoptera). Then, they were reared in the laboratory for adult observations. Antennae of $H$. liturata and $H$. albiventris have sensilla chaetica, trichodea, placodea (type I and II), coeloconica (type I and II), and ampullacea (or pore). Females of $H$. liturata have a total of about 10657 sensilla and males have about 12512, whereas females of $H$. albiventris have about 16490 sensilla and the males 24565 sensilla. Sensilla placodea are predominant in the antenna of males and females of both species.
\end{abstract}

\section{Introduction}

The genus Hoplopyga Thomson, 1880 (Coleoptera, Scarabaeidae, Cetoniinae, Gymnetini) includes 20 species distributed from Mexico to Argentina, of which 11 were registered in Brazil (Shaughney and Ratcliffe, 2015), namely: H. albiventris (Gory and Percheron, 1833), H. brasiliensis (Gory and Percheron, 1833), H. cerdani Antoine, 1998, H. liturata (Olivier, 1789), H. marginesignata (Gory and Percheron, 1833), H. miliaris (Gory and Percheron, 1833), H. multipunctata (Gory and Percheron, 1833), H. ocellata (Gory and Percheron, 1833), H. ravida (Janson, 1881), H. riparia Shaughney and Ratcliffe, 2015, and H. singularis (Gory and Percheron, 1833).

Adults of Hoplopyga have been noticed feeding on leaves, flowers, fruits, and plant sap (Ballou, 1937; Solís, 2004; Gonçalves and Louzada, 2005; Puker et al., 2012; Rodrigues et al., 2013, Shaughney and Ratcliffe, 2015; Kirmse and Ratcliffe, 2019), while larvae feed on mounds of termites (Isoptera) and decaying woods trunks (Luederwaldt, 1911; Vanin and Costa, 1984; Micó et al., 2001; Garcia et al., 2013; Puker et al., 2012, 2014; Shaughney and Ratcliffe, 2015).

Insect antennae are important sensory structures involved in the detection of odorants, and temperature, besides being tactile and

\footnotetext{
* Corresponding author:

E-mail: sergio@uems.br (S.R. Rodrigues).
}

gustative organs (Schneider, 1964; Hansson and Stensmyr, 2011). Antennal sensilla are responsible for reception of semiochemicals (or infochemicals), such as sexual or aggregative pheromones, and of other volatiles, helping insects to locate plants used as food and mating sites (Visser, 1986; Tegoni et al., 2004; Wee et al., 2016).

Adults of scarab beetles (Coleoptera, Scarabaeidae) use to swarm to find partners to copulate (Rodrigues et al., 2014, 2016). During the couple formation, these beetles usually use chemical communication detecting released odors using their antennal sensilla (Meinecke, 1975; Leal, 1998). Sensilla types and number vary with species but also between males and females within a species, especially for Scarabaeidae (Ochieng et al., 2002; Romero-López et al., 2004, 2010; Tanaka et al., 2006; Handique et al., 2017; Rodrigues et al., 2019).

The study of sensorial organs of insects is important to clarify questions about fine morphology, the process of communication, and habitat perception by these animals. The present paper aimed to describe the morphology of antennal sensilla of males and females of two species of phytophagous scarab beetles included in the genus Hoplopyga: $H$. albiventris and $H$. liturata. Larvae of $H$. liturata were collected from decaying woods, pupal instar lasted about 18 days (Garcia et al., 2013), and immatures were described by Morón e Arce (2002). In Brazil, 
the species prefer cerrado landscapes (Brazilian savanna) to urban parks (Correa et al., 2020). Hedström and Elmqvist (1985) observed $H$. liturata damaging stems of the vine species Gouania polygama (Jacq.) Urb. (Rhamnaceae) in Costa Rica to feed on its exudates. Such an interaction attracted the butterfly species Prepona laertes(Hübner, 1811) (Nymphalidae, Lepidoptera), which also fed on the vine exudates and directly on beetle excreta. The authors suggested that this interaction between the beetle and the butterfly could be a case of commensalism. Occasional copresence of cetoniine beetles and butterflies around sources of plant exudates have been sometimes observed (Di Iorio, 2014).

Luederwaldt (1911) found larvae of $H$. albiventris in termite mounds of Cornitermes sp. Also, Puker et al. (2014) noted the preference of this species for pastures due to the presence of mounds of Cornitermes in these agroecosystems regularly.

\section{Material and methods}

The study was conducted at the Universidade Estadual de Mato Grosso do Sul (UEMS), Campus of Cassilândia, Mato Grosso do Sul, Brazil.

Larvae of $H$. albiventris were collected from mounds of termites (Cornitermes cumulans (Kollar, 1832) (Isoptera: Termitidae)) between August 2017 and September 2018 in a pasture area (Urochloa decumbens Stapf, Poaceae). These mounds were open in the field. After collection, larvae were reared in the laboratory. Each larva was placed into plastic containers $(500 \mathrm{~mL})$ filled with the substrate used by immatures.

Adults of $H$. liturata were collected using traps baited with a banana and sugarcane juice mixture as an attractant. The species had been collected in recent studies using the same method as in Rondônia State (Puker et al., 2020a, 2020b). Each trap was constructed from a PET bottle ( $2 \mathrm{~L}$ ) with two $8 \times 5 \mathrm{~cm}$ side openings. Three traps were used between November and December 2018, two in a "Cerrado" (Brazilian savanna) fragment and one in a pasture area. They were installed about $1.5 \mathrm{~m}$ high from the soil. The attractant was replaced two times per week (methodology modified by Rodrigues et al., 2013).

The reared adults of $H$. albiventris and those of $H$. liturata collected were preserved in $70 \%$ alcohol. The adults of $H$. albiventris were identified by comparison with the material of the Museu de Zoologia da Universidade de São Paulo, while those of H. liturata by comparison with the material of the UEMS, Campus of Cassilândia. The revision of the genus Hoplopyga was also used for identifications (Shaughney and Ratcliffe, 2015).

Antennal sensilla were studied by scanning of antennal clubs taken using an electron microscope (SEM, model Zeiss EVO LS15) in the Departamento de Física e Química, Universidade Estadual Paulista (UNESP), Campus of Ilha Solteira, São Paulo State (a method by Tanaka et al., 2006). Antennae of 10 males and 10 females were dissected and maintained in 70\% alcohol. Afterwards, appendages were successively washed in $80 \%$ and $90 \%$ ethanol for 15 minutes each, and then $100 \%$ ethanol for 20 minutes. The pieces were taken to dry in a $\mathrm{CO}_{2}$ critical point dryer (model Leica ${ }^{\circledR}$ CPD300).

Antennal lamellae were also mounted on slides for optical microscope observation (model Nikon E200), following the method of RomeroLópez et al. (2004).

Sensilla terminology follows Keil (1999). Meinecke (1975) was used as an alternative sensilla terminology (in brackets) to easily term comparison. The Student's t-test was used to compare the distribution of sensilla.

\section{Results}

Adults of $H$. liturata and $H$. albiventris have antennae with ten antennomeres, and the antennal club has three antennomeres (Fig. 1).

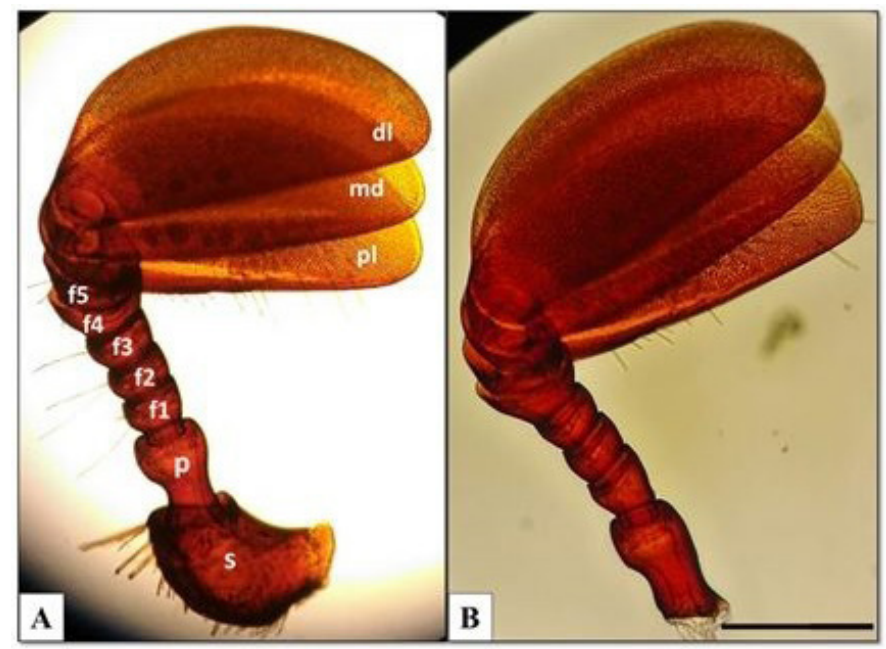

Figure 1 Hoplopyga liturata, antenna. A) female, B) male. (s) scape, (p) pedicel, (f1-f5) flagellomeres of funicle, ( $\mathrm{pl}$ ) proximal lamella, (md) medial lamella, (md) distal lamella. Scale $=200 \mu \mathrm{m}$.

\section{Hoplopyga liturata}

Antennae of male and females are quite similar to each other, but males have medial lamella longer than to females (Table 1 e Fig. 2).

Lamellae have sensilla trichodea, chaetica, placodea, coeloconica and ampullacea. Sensilla trichodea are hair-like, thin, and long, and found on edges of lamellae in both genders. Sensilla chaetica are like sensilla trichodea but short and grouped all together in a brushlike structure in the outer surface of the proximal lamella. Sensilla trichodea and sensilla chaetica have been sometimes termed together as sensilla chaetica (e.g., Zauli et al., 2016) or as sensilla trichodea (e.g., Bohacz et al., 2020). Hair-like sensilla cannot be easily separated into two categories (as used here and by the generalization for insects by Keil, 1999). They are quite variable in length and shape (with acute or blunt apex, simple or serrate, smooth or with perforations or striae; see Meinecke (1975) and Bohacz et al. (2020) for sensilla comparison between scarab beetles). The present study considered sensilla trichodea to be long setae distributed in all antennomeres and sensilla chaetica the minor setae grouped in a brush-like structure (Fig. 3).

The sensilla placodea found are type I (Meinecke, 1975: sensilla B2; Fig. 4A) and type II (Meinecke, 1975: sensilla B3; Fig. 4B). These are the predominant types of antennal sensilla found along lamellae in both sexes except on the outer side of the proximal lamella.

The sensilla placodea type I are somewhat rounded and have a diameter of $8.2 \pm 2.1 \mu \mathrm{m}(\mathrm{n}=50$; Fig. $4 \mathrm{~A})$. These sensilla are predominant in the posterior third of the outer side of proximal lamella (Fig. 4C).

The sensilla placodea type II are rounded and have diameter of $9.8 \pm 3.1$ ( $n=50$; Fig. 4D). These sensilla are predominant in the anterior half of the inner side of the medial lamella.

The sensilla coeloconica found are type I (short with acute apex; Meinecke, 1975: sensilla L1; Fig. 5B) and type II (short with blunt apex; Meinecke, 1975: sensilla L3; Fig. 5C). Both are found in the inner side of proximal and distal lamellae and inner and outer sides of medial lamella (sides of lamellae that can be closed). They are distributed mainly in the central areas of lamellae (Fig. 5A).

Several sensilla ampullacea (pore) are found in all lamella (Fig. 6A-B).

Males of $H$. liturata have more sensilla than females. Females $(\mathrm{n}=08)$ have 10657 sensilla, of which 10279 (96.45\%) are sensilla placodea and 378 (3.55\%) are coeloconica. Males ( $\mathrm{n}=08$ ) have 12512 sensilla, of which 11983 (95.77\%) are sensilla placodea and $529(4.23 \%)$ are coeloconica (Table 2 ). 
Table 1

Size of antennal lamellae of Hoplopyga liturata.

\begin{tabular}{|c|c|c|c|c|c|c|}
\hline \multirow{2}{*}{ Lamellae } & \multicolumn{2}{|c|}{ length $(\mu \mathrm{m})$} & \multirow{2}{*}{$P$} & \multicolumn{2}{|c|}{ width $(\mu \mathrm{m})$} & \multirow{2}{*}{$P$} \\
\hline & Female & Male & & Female & Male & \\
\hline Proximal & $1096.5 \pm 10$ & $1119.0 \pm 78$ & NS & $482.8 \pm 14$ & $498.4 \pm 36$ & NS \\
\hline Medial & $1015.4 \pm 12$ & $1127.0 \pm 10$ & $<0,05$ & $519.0 \pm 12$ & $504.0 \pm 12$ & NS \\
\hline Distal & $1082.4 \pm 41$ & $1127.20 \pm 58$ & NS & $458.6 \pm 2$ & $465.0 \pm 48$ & NS \\
\hline
\end{tabular}
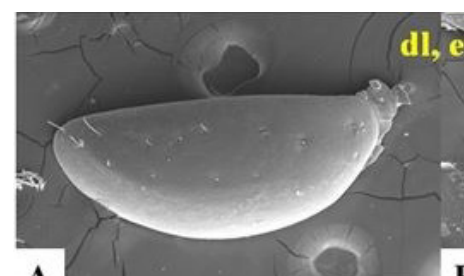

A

$$
\text { B }
$$

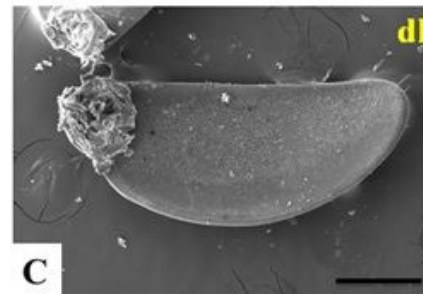

d!, in

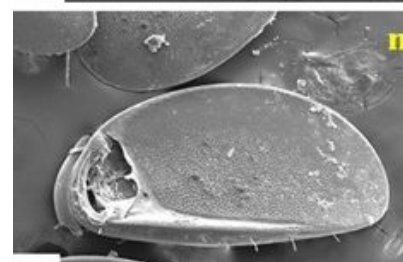

D

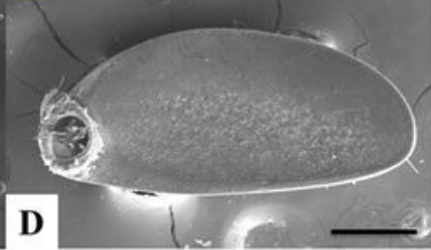

E a.

d, in
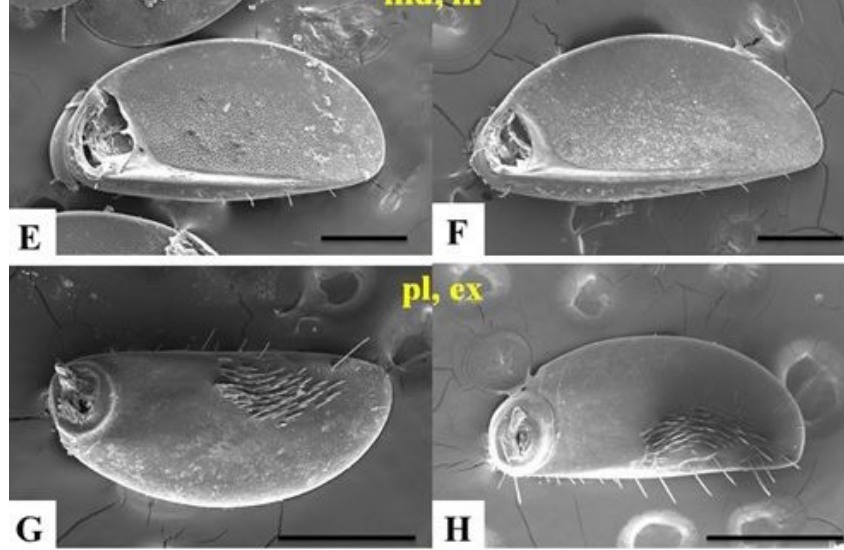

$\mathrm{pl}, \mathrm{ex}$

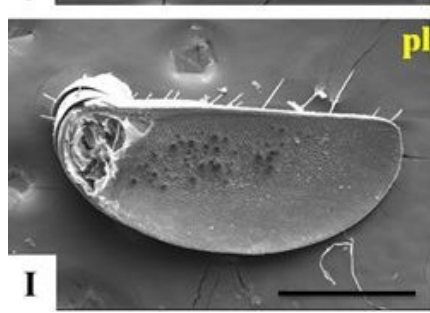

H

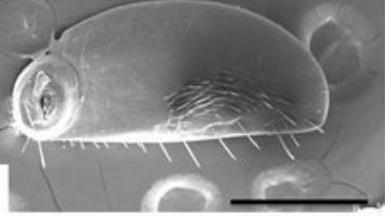

$\mathrm{pl}$, in

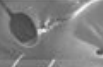

Figure 2 Hoplopyga liturata, antennal lamella of female (left: A, C, E, G, I) and male (right: B, D, F, H, J). (dl) distal lamella; (ex) outer side; (in) inner side; (md) medial lamella; (pl) proximal lamella. Scale = A, B, C, D, E, F, J: $100 \mu \mathrm{m} ; \mathrm{G}, \mathrm{H}, \mathrm{I}: 200 \mu \mathrm{m}$.

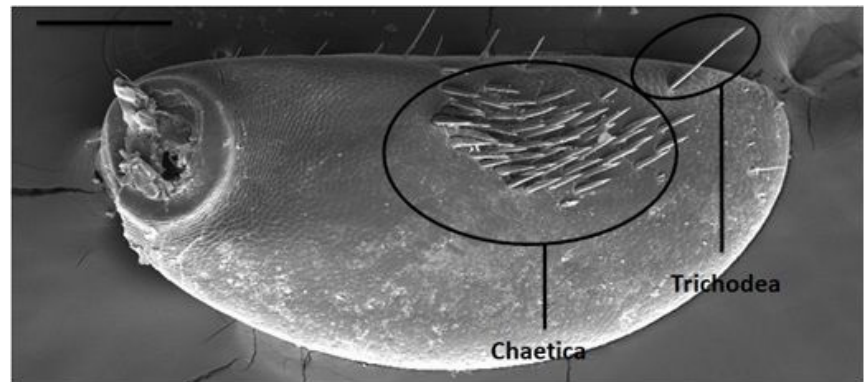

Figure 3 Hoplopyga liturata, proximal lamella of female, proximal lamella, outer side. Distribution of sensilla chaetica and sensilla trichodea. Scale $=200 \mu \mathrm{m}$.
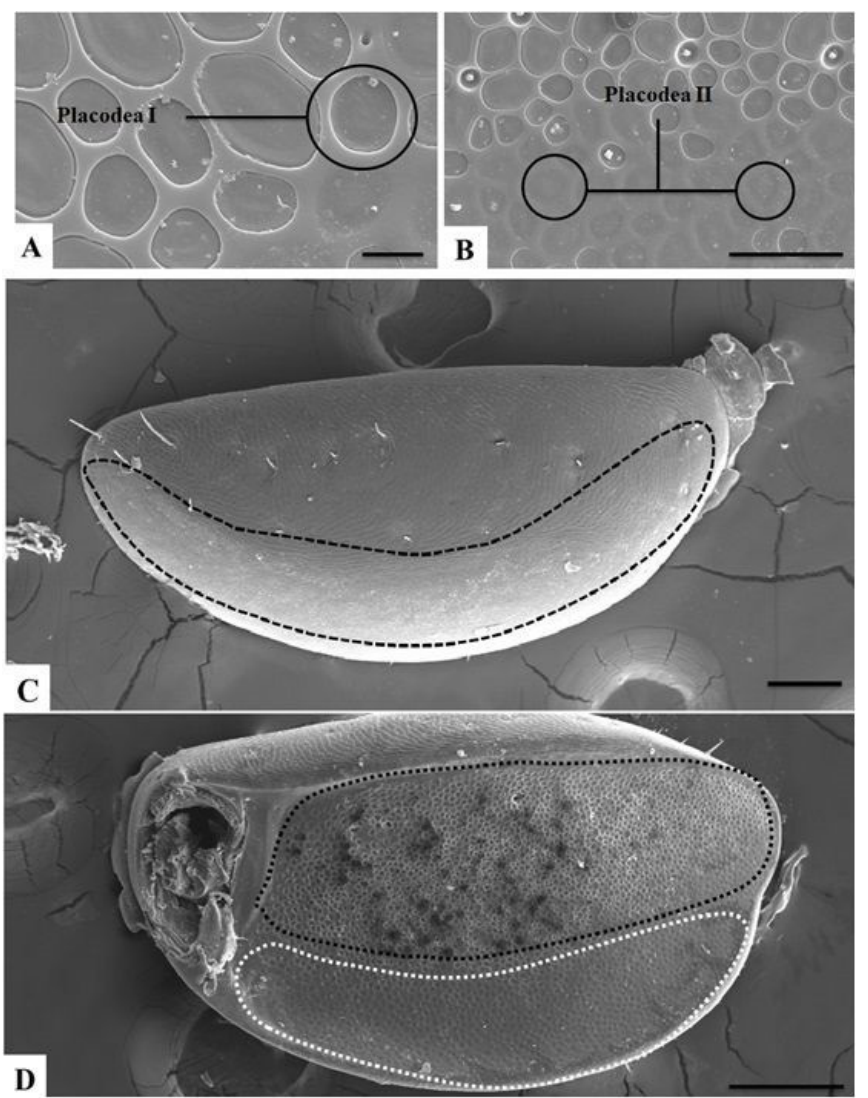

Figure 4 Antenna of Hoplopyga female. A-C) H. liturata; D) H. albiventris A) sensilla placodea type I; B) sensilla placodea type II; C) distal lamella, outer side, posterior area (white dotted line) with sensilla placodea type I, D) proximal lamella, inner side, anterior area (black dotted line) with sensilla placodea type I mixed with type II, posterior area (white dotted line) with type I homogeneously distributed. Scale =A: $2 \mu \mathrm{m}$; B: $20 \mu \mathrm{m}$; C, D: $100 \mu \mathrm{m}$.

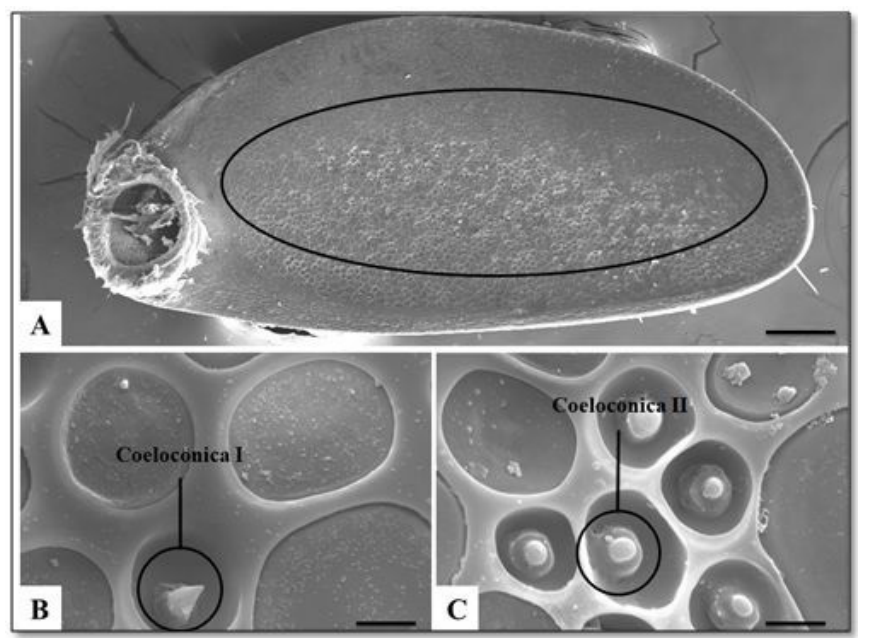

Figure 5 Hoplopyga liturata, distal lamella, inner side. A) distribution of sensilla coeloconica type I and II; B) sensilla coeloconica type I; C) sensilla coeloconica type II. Scale $=$ A: $100 \mu \mathrm{m} ; \mathrm{B}, \mathrm{C}: 2 \mu \mathrm{m}$. 


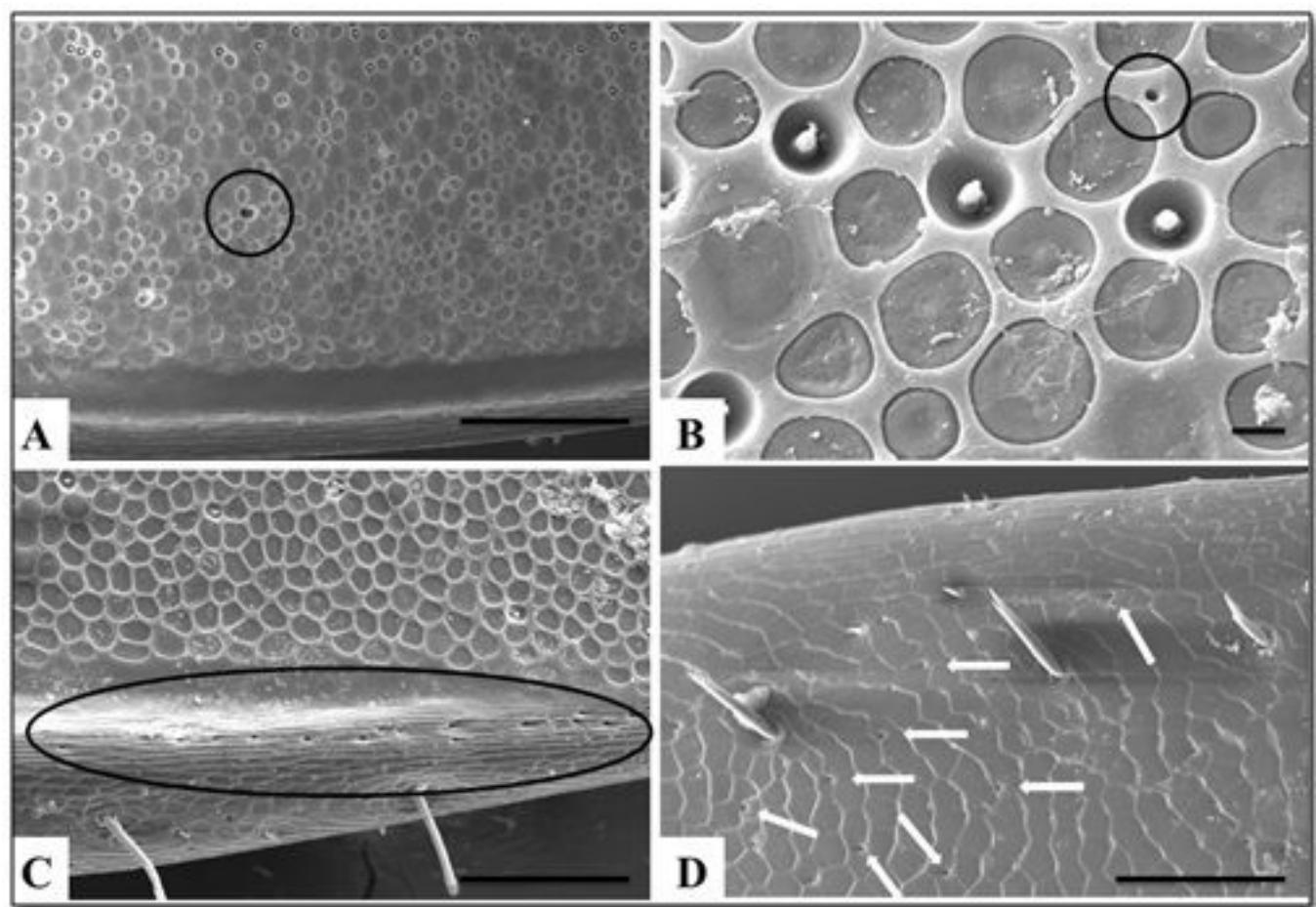

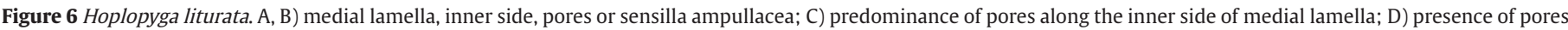
on the outer side of the distal lamella. Scale =A, C, D: $20 \mu \mathrm{m} ; \mathrm{B}: 2 \mu \mathrm{m}$.

Table 2

Number of sensilla placodea and sensilla coeloconica of Hoplopyga liturata.

\begin{tabular}{|c|c|c|c|c|c|c|c|}
\hline \multirow{2}{*}{ Sensilla } & \multicolumn{2}{|c|}{ proximal lamella } & \multicolumn{2}{|c|}{ medial lamella } & \multicolumn{2}{|c|}{ distal lamella } & \multirow{2}{*}{ Total } \\
\hline & outer & inner & outer & inner & outer & inner & \\
\hline \multicolumn{8}{|c|}{ Female } \\
\hline Placodea & 0 & 2126 & 2254 & 2243 & 1596 & 2060 & 10279 \\
\hline Coeloconica & 0 & 118 & 41 & 105 & 0 & 114 & 378 \\
\hline Total & 0 & 2244 & 2295 & 2348 & 1596 & 2174 & 10657 \\
\hline \multicolumn{8}{|c|}{ Male } \\
\hline Placodea & 0 & 3035 & 2565 & 2775 & 1000 & 2608 & 11983 \\
\hline Coeloconica & 0 & 172 & 85 & 113 & 0 & 159 & 529 \\
\hline Total & 0 & 3207 & 2650 & 2888 & 1000 & 2767 & 12512 \\
\hline
\end{tabular}

Hoplopyga albiventris

The proximal and distal lamellae of male antennae are longer than those of females (Table 3 and Fig. 7).

The antennae of $H$. albiventris are like those of $H$. liturata (Fig. 3) and both species have sensilla of the same types and with similar distribution. The differences of antennal structure of $H$. albiventris (regarding $H$. liturata described before) are listed below.

Sensilla placodea of type I have a diameter of $8.8 \pm 2.1 \mu \mathrm{m}(\mathrm{n}=50)$ and those of type II have diameter of $10.1 \pm 2.1(n=50)$.

Females ( $n=08)$ have 16490 sensilla, of which 15779 (95.69\%) are sensilla placodea and 711 (4.31\%) are coeloconica. Males $(n=08)$ have 25149 sensilla, of which 24565 (97.68\%) are sensilla placodea and $584(2.32 \%)$ are coeloconica (Table 4).

\section{Discussion}

Adults of $H$. liturata and $H$. albiventris have similar antennae structure, shape, and size, but the amount of sensilla is quite different between both species. Male antennae are slightly longer than those of females and have more sensilla than female antennae. Sexual dimorphism in scarab beetle antennae have been frequently reported (e.g., Allsopp, 1990; Romero-López et al., 2004; Mutis et al., 2014) and it could be related to how species find sexual partners or food sources by detecting volatiles with antennae.

Scarab beetles have two main and sometimes intermixed processes of aggregation: 1) beetles group around a food source using conspecific aggregative pheromones (e.g., Oryctes rhinoceros (Linnaeus, 1758), Dynastinae, studied by Renou et al., 1998) or plant volatiles (e.g., Melolontha hippocastani Fabricius, 1801, Melolonthinae, studied by Ruther et al., 2000; 2) beetles can group around potential sexual partners that releases sexual infochemicals (e.g., Phyllophaga anxia (LeConte, 1850), Melolonthinae, studied by Ochieng et al., 2002).

Sexual pheromones and plant volatiles are used together by Melolontha hippocastani(Ruther et al., 2000) and some Rutelinae (e.g., Anomala cuprea (Hope, 1839) and Phyllopertha diversa Waterhouse, 1875, studied by Hansson et al., 1999; Larsson et al., 2001) for example.

In Cetoniinae, plant volatiles are important for aggregation of the genus Pachnoda (Cetoniini; Larsson et al. 2003a; Bengtsson et al., 2011). For Cotinis nitida (Linnaeus, 1758) (Gymnetini), Domek and Johnson $(1987,1988,1990)$ found evidence of females releasing sexual attractant 
Table 3

Size of antennal lamellae of Hoplopyga albiventris.

\begin{tabular}{|c|c|c|c|c|c|c|}
\hline \multirow{2}{*}{ Lamellae } & \multicolumn{2}{|c|}{ length $(\mu \mathrm{m})$} & \multirow{2}{*}{$P$} & \multicolumn{2}{|c|}{ width $(\mu \mathrm{m})$} & \multirow{2}{*}{$P$} \\
\hline & Female & Male & & Female & Male & \\
\hline Proximal & $1155.0 \pm 55$ & $1162.0 \pm 27$ & $<0,05$ & $615.8 \pm 10$ & $547.2 \pm 12$ & NS \\
\hline Medial & $1100.6 \pm 29$ & $1116.1 \pm 87$ & NS & $627.0 \pm 5$ & $587.1 \pm 59$ & NS \\
\hline Distal & $1042.2 \pm 26$ & $1210.0 \pm 70$ & $<0,05$ & $520.0 \pm 13$ & $509.2 \pm 27$ & $<0.05$ \\
\hline
\end{tabular}

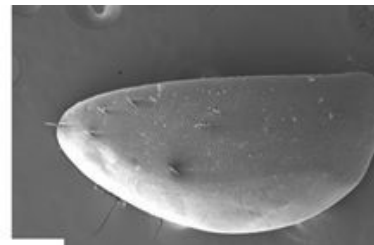

A
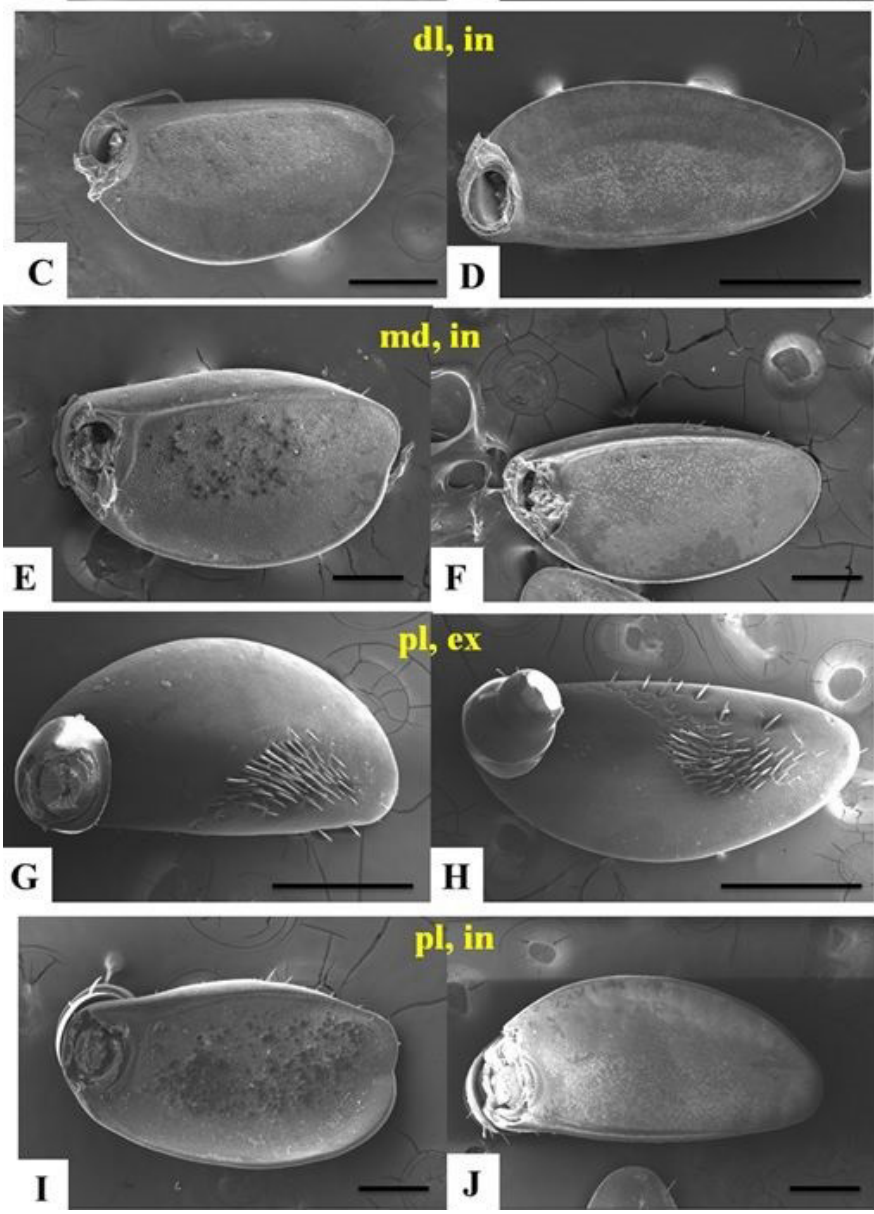

Figure 7 Hoplopyga albiventris, antenna female (left: A, C, E, G, I) and male (right: B, D, F, H, J). (dl) distal lamella; (ex) outer side; (in) inner side; (md) medial lamella; (pl) proximal lamella. Scale = A, C, E, F, I, J: $100 \mu \mathrm{m}$; B, D, G, H: $200 \mu \mathrm{m}$.

and males and females releasing aggregation volatiles related to the beetle diet (sites with fruits and feeding males attract more males and females than fruit alone or females alone). Therefore, both aggregation and sexual infochemicals could work together in the subfamily. Another possibility is that males attract females with sexual pheromones, as in Osmoderma eremita(Scopoli, 1763) (Cetoniinae, Osmodermatini, studied by Larsson et al., 2003b), perhaps to guide females to a suitable habitat.

In some phytophagous scarab beetles (e.g., Maladera matrida Argaman, 1986, Melolonthinae, studied by Harari et al., 1994), males first find and damage a host plant and then attract females. Other scarab beetles have been reported with both behaviors: females directly attract males and females are attracted to damaged plants by males (e.g., Popillia japonica Newman, 1841, Rutelinae, studied by Smith 1923).

However, it is still not clear whether Hoplopyga males are directly attracted to females or they firstly find a food source and then attract females. It is also unclear whether these are behaviors related to antennal sexual dimorphism.

\section{Antennal sensilla}

Sensilla trichodea and chaetica, both present mainly in the outer surface of lamella, were associated with mechanoreceptors or gustative organs (contact chemoreceptors) and sometimes with airflow and sound detection (Keil, 1999; Ochieng et al., 2002; Romero-López et al., 2004; Mutis et al., 2014).

Both $H$. albiventris and $H$. liturata have large amounts of sensilla placodea, which are more abundant in males than in females of both species. This sort of sensillum was considered the main sexual pheromone receptor, as in Anomala cuprea (Leal and Mochizuki, 1993), Phyllopertha diversa (Nikonov et al., 2001), and Popillia japonica(Kim and Leal, 2000). Larsson et al. (2001) found that the sensilla placodea of $A$. cuprea antennae are both sexual pheromones and plant volatile receptors and that where they are is decisive for their function.

Sensilla coeloconica are arranged mainly in the central area of lamellae. In antennal pedicel, Shao et al. (2019) suggested that this kind of sensilla respond to humidity and temperature (hygro-receptors and thermo-receptors). For lamellae, Kim and Leal (2000) and RomeroLópez et al. (2004) considered sensilla coeloconica as receptors to plant volatiles.

The numerous sensilla ampullacea, visible as small pores, were associated with detection of odorants or $\mathrm{CO}_{2}$ (Schneider, 1964; Keil and Steinbrecht, 1984; Keil, 1999).

The antennal variation between $H$. albiventris and $H$. liturata could be related to how adults explore their habitats. Hoplopyga albiventris adults are found in open areas such as pastures (Puker et al., 2014), while immatures in termite mounds (Luederwaldt, 1911). Otherwise, H. liturata adults are found in tropical rainforests and Cerrado biomes (Shaughney and Ratcliffe, 2015; Correa et al., 2020), while larvae in rotten woods (Neita-M. et al., 2006; Garcia et al., 2013).

Hoplopyga albiventris adults have more antennal sensilla (males: 24565, females 16490) than H. liturata (males: 12512, females 10657). Perhaps such an abundance of antennal sensilla in $H$. albiventris is related to the detection of termite mounds or food sources in open areas. However, the number of antennal sensilla in other Cetoniinae species (found or not associated with termites) are scarce for such an assumption.

The inner parts of Hoplopyga lamellae have two main areas, one homogeneous with sensilla placodea type I and another heterogeneous with placodea (type I and II) and some coeloconica (Fig. 4). In ruteline beetles ( A. cuprea), Larsson et al. (2001) observed that the homogeneous area is responsible for the detection of sexual pheromones, while the heterogeneous is related to the detection of other volatiles. 
Table 4

Number of sensilla placodea and sensilla coeloconica of Hoplopyga albiventris.

\begin{tabular}{|c|c|c|c|c|c|c|c|}
\hline \multirow{2}{*}{ Sensilla } & \multicolumn{2}{|c|}{ proximal lamella } & \multicolumn{2}{|c|}{ medial lamella } & \multicolumn{2}{|c|}{ distal lamella } & \multirow{2}{*}{ Total } \\
\hline & outer & inner & outer & inner & outer & inner & \\
\hline \multicolumn{8}{|c|}{ Female } \\
\hline Placodea & 0 & 3569 & 2686 & 3379 & 2801 & 3344 & 15779 \\
\hline Coeloconica & 0 & 201 & 136 & 144 & 0 & 230 & 711 \\
\hline Total & 0 & 3770 & 2822 & 3523 & 2801 & 3574 & 16490 \\
\hline \multicolumn{8}{|c|}{ Male } \\
\hline Placodea & 0 & 5041 & 5516 & 5706 & 3035 & 5267 & 24565 \\
\hline Coeloconica & 0 & 142 & 81 & 110 & 0 & 251 & 584 \\
\hline Total & 0 & 5183 & 5597 & 5816 & 3035 & 5518 & 25149 \\
\hline
\end{tabular}

The kind of sensilla found in Hoplopyga is like that found in other Old-World Cetoniinae genera (Meinecke, 1975; Baker and Monroe, 2005; Zauli et al., 2016; Bohacz et al., 2020). More data on quantity and distribution of antennal sensilla are needed to further comparison between different Cetoniinae species.

\section{Acknowledgments}

Juares Fuhrmann thanks Sônia A. Casari (MZSP) for her supervision. Also to the Instituto Nacional de Ciência e Tecnologia (INCT) de Semioquímicos na Agricultura (FAPESP 2014/50871-0 and CNPq 465511/2014-7) for the financial support.

\section{Conflicts of interest}

The authors declare no conflicts of interest.

\section{Author contribution statement}

CGC performed the collections in the field and performed the photos in scanning electron microscopy. CGC, SRR and JF performed the analyzes and interpretations of the data. CGC, SRR and JF contributed to the critical review and addition of intellectual content. CGC, SRR and JF made the corrections and final writing.

\section{References}

Allsopp, P. G., 1990. Sexual dimorphism in the adult antennae of Antitrogus parvulus Britton and Lepidiota negatoria Blackburn (Coleoptera: Scarabaeidae: Melolonthinae). J. Aust. Entomol. Soc. 29, 261-166. https://doi.org/10.1111/j.1440-6055.1990.tb00360.x.

Baker, G. T., Monroe, W. A., 2005. Sensilla on the adult and larval antennae of Cotinis nitida (Coleoptera: scarabaeidae). Microsc. Microanal. 11 (Suppl. 2), 170-171. https://doi.org/10.1017/S1431927605500448.

Ballou, C. H., 1937. Insect notes from Costa Rica in 1936. Insect Pest Surv. Bull. 17, 483-590.

Bengtsson, J. M., Khbaish, H., Reinecke, A., Wolde-Hawariat, Y., Negash, M., Seyoum, E., Hansson, B. S., Hillbur, Y., Larsson, M. C., 2011. Conserved, highly specialized olfactory receptor neurons for food compounds in 2 congeneric scarab beetles, Pachnoda interrupta and Pachnoda marginata. Chem. Senses 36, 499-513. https://doi. org/10.1093/chemse/bjr002.

Bohacz, C., Harrison, J. du G., Ahrens, D., 2020. Comparative morphology of antennal surface structures in pleurostict scarab beetles (Coleoptera).Zoomorphology 139, 327-346. https://doi.org/10.1007/ s00435-020-00495-0.

Correa, C.M.A., Silva, P.G., Lara, M.A., Puker, A., 2020. Spatiotemporal patterns of $\beta$-diversity of flower chafer beetles in urban park and natural reserve sites in Brazilian Cerrado. Int. J. Trop. Insect Sci. 41, 681-691. https://doi.org/10.1007/s42690-020-00257-x.

Di Iorio, O., 2014. A review of the natural history of adult Cetoniinae (Coleoptera: Scarabaeidae) from Argentina and adjacent countries. Zootaxa 3790, 281-318. https://doi.org/10.11646/zootaxa.3790.2.3.

Domek, J. M., Johnson, D. T., 1987. Evidence of a sex pheromone in the green June Beetle, Cotinis nitida (Coleoptera: scarabaeidae). J. Entomol. Sci. 22, 264-267. https://doi.org/10.18474/0749-8004-22.3.264.

Domek, J. M., Johnson, D. T., 1988. Demonstration of semiochemically induced aggregation in the green June beetle, Cotinis nitida (L.) (Coleoptera: scarabaeidae). Environ. Entomol. 17, 147-149. https:// doi.org/10.1093/ee/17.2.147.

Domek, J. M., Johnson, D. T., 1990. Inhibition of aggregation behavior in the green june beetle (Coleoptera: Scarabaeidae) by antibiotic treatment of food substrate. Environ. Entomol. 19, 995-1000. https://doi.org/10.1093/ee/19.4.995.

Garcia, F. P., Rodrigues, S. R., Bagnara, C. A. C., Oliveira, D. S., 2013. Survey of saproxylophagous Melolonthidae (Coleoptera) and some biological aspects in Aquidauana, MS. Biota Neotrop. 13, 38-43. https://doi. org/10.1590/S1676-06032013000300004.

Gonçalves, T. T., Louzada, J. N. C., 2005. Estratificação vertical de coleópteros carpófilos (Insecta: Coleoptera) em fragmentos florestais do sul do estado de Minas Gerais, Brasil. Ecol. Austral 15, 101-110.

Handique, G., Bhattacharyya, B., Baruah, A. A. L. H., Boruah, R., 2017. Antenna morphology and sensilla microstructure of the male and female scarab beetle, Lepidiota mansueta Burmeister (Coleoptera: scarabaeidae). Invertebr. Reprod. Dev. 61, 200-205. https://doi.org /10.1080/07924259.2017.1287784.

Hansson, B. S., Larsson, M. C., Leal, W. S., 1999. Green leaf volatiledetecting olfatory receptor neurones display very high sensitivity and specificity in a scarab beetle. Physiol. Entomol. 24, 121-126. https://doi.org/10.1046/j.1365-3032.1999.00121.x.

Hansson, B. S., Stensmyr, M. C., 2011. Evolution of insect olfaction. Neuron 72, 698-711. https://doi.org/10.1016/j.neuron.2011.11.003.

Harari, A. R., Ben-Yakir, D., Rosen, D., 1994. Mechanism of aggregation behavior in Maladera matrida Argaman (Coleoptera: scarabaeidae). J. Chem. Ecol. 20, 361-371. https://doi.org/10.1007/BF02064443.

Hedström, I., Elmqvist, T., 1985. Prepona butterflies (Nyrnphalidae) and Hoplopyga beetles (Scarabaeidae) on the same food source during the Neotropical dry season - a case of commensalism? Rev. Biol. Trop. 32, 313-315.

Keil, T. A., 1999. Chapter 1. Morphology and development of the peripheral olfactory organs. In: Hansson, B. (Ed.), Insect olfaction. Springer, Berlin, pp. 6-44.

Keil, T. A., Steinbrecht, R. A., 1984. Mechanosensitive and olfactory sensilla of insects. In: King, R.C., Akai, H. (Eds.), Insect ultrastructure. Vol. 2. Plenum, New York, pp. 477-516.

Kim, J. Y., Leal, W. S., 2000. Ultrastructure of pheromone-detecting sensillum placodeum of the Japanese beetle, Popillia japonica 
Newmann (Coleoptera: scarabaeidae). Arthropod Struct. Dev. 29, 121-128. https://doi.org/10.1016/S1467-8039(00)00022-0.

Kirmse, S., Ratcliffe, B. C., 2019. Composition and host-use patterns of a scarab beetle (Coleoptera: Scarabaeidae) community inhabiting the canopy of a lowland tropical rainforest in southern Venezuela. The Coleop. Bull. 73, 149-167. https://doi.org/10.1649/0010-065X-73.1.149.

Larsson, M. C., Leal, W. S., Hansson, B. S., 2001. Olfactory receptor neurons detecting plant odors and male volatiles in Anomala cuprea beetles (Coleoptera: scarabaeidae).J. Insect Physiol. 47, 1065-1076. https:// doi.org/10.1016/S0022-1910(01)00087-7.

Larsson, M. C., Stensmyr, M. C., Bice, S. B., Hansson, B. S., 2003a. Attractiveness of fruit and flower odorants detected by olfactory receptor neurons in the fruit chafer Pachnoda marginata. J. Chem. Ecol. 29, 1253-1268. https://doi.org/10.1023/a:1023893926038.

Larsson, M. C., Herin, J., Svensson, G. P., Tolasch, T., Francke, W., 2003b. Characteristic odor of Osmoderma eremita identified as a malereleased pheromone. J. Chem. Ecol. 29, 575-587. https://doi. org/10.1023/a:1022850704500.

Leal, W. S., 1998. Chemical ecology of phytophagous scarab beetles. Annu. Rev. Entomol. 4, 39-61. https://doi.org/10.1146/annurev. ento.43.1.39.

Leal, W. S., Mochizuki, F., 1993. Sex pheromone reception in the scarab beetle Anomala cuprea enantiomeric discrimination by sensilla placodea. Naturwissenschaften 80, 278-281. https://doi.org/10.1007/ BF01135914.

Luederwaldt, G., 1911. Quatro Lamellicorneos termitophilos. Rev. Mus. Paul. 8, 405-413.

Meinecke, C. C., 1975. Riechsensillen und Systematik der Lamellicornia (Insecta, Coleoptera). Zoomorphologie 82, 1-42.

Micó, E., Hall, W. E., Ratcliffe, B. C., 2001. Descriptions of the larvae of Hoplopyga singularis (Gory and Percheron) and Hologymnetis cinerea (Gory and Percheron) with a revised key to the larvae of new world Gymnetini(Coleoptera: Scarabaeidae: Cetoniinae). The Coleop. Bull. 55, 205-217. https://doi.org/10.1649/0010-065X(200 1)055[0205:DOTLOH]2.0.CO;2.

Morón, M. A., Arce, R., 2002. Descriptions of the immature stages of five Mexican species of Gymnetini (Coleoptera: Scarabaeidae: Cetoniinae). Proc. Entomol. Soc. Wash. 104, 1036-1054.

Mutis, A., Palma, R., Alvear, M., Morón, M., Quiroz, A., 2014. Morphology and distribution of sensilla on the antennae of Hylamorpha elegans Burmeister (Coleoptera: scarabaeidae). Neotrop. Entomol. 43, 260-265. https://doi.org/10.1007/s13744-014-0208-y.

Neita-M., J.C., Orozco-A., J., Ratcliffe, B., 2006. Escarabajos (Scarabaeidae: Pleurosticti) de la selva baja del bosque pluvial tropical "BP-T", Chocó, Colombia. Acta Zool. Mex. 22 (2), 1-32.

Nikonov, A. A., Valiyaveettil, J. T., Leal, W. S., 2001. A photoaffinity-labeled green leaf volatile compound 'tricks' highly selective and sensitive insect olfactory receptor neurons. Chem. Senses 26, 49-54. https:// doi.org/10.1093/chemse/26.1.49.

Ochieng, S. A., Robbins, P. S., Roelofs, W. L., Baker, T. C., 2002. Sex pheromone reception in the scarab beetle Phyllophaga anxia (Coleoptera: scarabaeidae). Ann. Entomol. Soc. Am. 9, 97-102. https://doi.org/10.1603/0013-8746(2002)095[0097:SPRITS]2.0.CO;2.

Puker, A., Ad'Vincula, H. L., Korasaki, V., Ferreira, F. N. F., Orozco, J., 2014. Biodiversity of Cetoniinae beetles (Coleoptera: Scarabaeidae) in introduced and native habitats in the Brazilian Atlantic Forest. Entomol. Sci. 17, 309-315. https://doi.org/10.1111/ens.12069.

Puker, A., Correa, C.M.A, Butzske, L.S., Pacheco, R.P., 2020a. Using aerial fruit-baited traps with different naturally fermented baits to survey scarab beetles in the Amazon rainforest. Studies Neotrop. Fauna Environ. 55(3), 1-6. https://doi.org/10.1080/01650521.2020.1786921.
Puker, A., Correa, C. M. A., Silva, A. S., Silva, J. V. O., Korasaki, V., Grossi, P. C., 2020b. Effects of fruit-baited trap height on flower and leaf chafer scarab beetles sampling in Amazon rainforest. Entomol. Sci. 23 (3), 245-255. https://doi.org/10.1111/ens.12418.

Puker, A., Lopes-Andrade, C., Rosa, C. S., Grossi, P. C., 2012. New records of termite hosts for two species of Hoplopyga, with notes on the life cycle of Hoplopyga brasiliensis (Coleoptera: Scarabaeidae: Cetoniinae). Ann. Entomol. Soc. Am. 105, 872-878. https://doi. org/10.1603/AN12068.

Renou, M., Tauban, D., Morin, J. P., 1998. Structure and function of antennal pore plate sensilla of Oryctes rhinoceros (L.) (Coleoptera: dynastidae). Int. J. Insect Morphol. Embryol. 27, 227-233. https:// doi.org/10.18474/0749-8004-22.3.264.

Rodrigues, S. R., Fuhrmann, J., Amaro, R. A., 2019. Aspects of mating behavior and antennal sensilla in Anomala inconstans Burmeister, 1844 (Coleoptera: Scarabaeidae: Rutelinae). Biota Neotrop. 19, 1-7. https://doi.org/10.1590/1676-0611-BN-2018-0664.

Rodrigues, S. R., Gomes, E. S., Bento, J. M. S., 2014. Sexual dimorphism and mating behavior in Anomala testaceipennis. J. Insect Sci. 14, 210-210. https://doi.org/10.1093/jisesa/ieu072.

Rodrigues, S. R., Morón, M. A., Gomes, E. S., Bento, J. M. S., 2016. Morphology of immature stages and mating behavior in Liogenys fusca(Blanchard) (Coleoptera, Melolonthidae, Melolonthinae). Rev. Bras. Entomol.60, 284-289. https://doi.org/10.1016/j.rbe.2016.06.005.

Rodrigues, S. R., Oliveira, J. L. N., Bagnara, C. A. C., Puker, A., 2013. Cetoniinae (Coleoptera: Scarabaeidae) attracted to fruitbaited traps near Aquidauana, Mato Grosso do Sul, Brazil. The Coleop. Bull. 67, 119-122. https://doi.org/10.1649/0010-065X-67.2.119.

Romero-López, A. A., Arzuffi, R., Valdez, J., Morón, M. A., CastrejónGómez, V., Villalobos, F. J., 2004. Sensory organs in the antennae of Phyllophaga obsoleta (Coleoptera: melolonthidae). Ann. Entomol. Soc. Am. 97, 1306-1313. https://doi.org/10.1603/00138746(2004)097[1306:SOITAO]2.0.CO;2.

Romero-López, A. A., Morón, M. A., Valcez, J., 2010. Sexual dimorphism in antennal receptors of Phyllophaga ravida Blanchard (Coleoptera: Scarabaeoidea: Melolonthidae). Neotrop. Entomol. 39, 957-966.

Ruther, J., Reinecke, K., Tolasch, T., Francke, W., Hilker, M., 2000. Mate finding in the forest cockchafer, Melolontha hippocastani, mediated by volatiles from plants and females. Physiol. Entomol. 25, 172-179. https://doi.org/10.1046/j.1365-3032.2000.00183.x.

Schneider, D., 1964. Insect antennae. Annu. Rev. Entomol. 9, 103-122. Shao, K. M., Sun, Y., Wang, W. K., Chen, L. A., 2019. SEM study of antennal sensilla in Maladera orientalis Motschulsky (Coleoptera: Scarabaeidae: Melolonthinae). Micron 119, 17-23. https://doi. org/10.1016/j.micron.2019.01.004.

Shaughney, J. M., Ratcliffe, B. C., 2015. A monographic revision of the genus Hoplopyga Thomson, 1880 (Coleoptera: Scarabaeidae: Cetoniinae: Gymnetini). The Coleop. Bull. 69, 579-638. https://doi. org/10.1649/0010-065X-69.4.579.

Smith, L. B., 1923. Feeding habits of the Japanese beetle which influence its control. Bulletin. U. S. Dep. Agric. 1154, 1-11. https://doi. org/10.5962/bhl.title.109044.

Solís, A., 2004. Escarabajos fruteros de Costa Rica. Instituto Nacional de Biodiversidad, Santo Domingo de Heredia, Costa Rica.

Tanaka, S., Yukuhiro, F., Wakamura, S., 2006. Sexual dimorphism in body dimensions and antennal sensilla in the white grub beetle, Dasylepida ishigakiensis(Coleoptera: scarabaeidae). Appl. Entomol. Zool. 41, 455-462. https://doi.org/10.1303/aez.2006.455.

Tegoni, M., Campanacci, V., Cambillau, C., 2004. Structural aspects of sexual attraction and chemical communication in insects. Trends Biochem. Sci. 29, 257-264. https://doi.org/10.1016/j.tibs.2004.03.003. 
Vanin, S. A., Costa, C., 1984. Larvae of Neotropical Coleoptera. IX: Scarabaeidae, Cetoniinae, Gymnetini. Rev. Bras. Entomol. 28, 329-335.

Visser, J. H., 1986. Host odor perception in phytophagous insects. Annu. Rev. Entomol. 31, 121-144. https://doi.org/10.1146/annurev. en.31.010186.001005.

Wee, S. L., Oh, H. W., Park, K. C., 2016. Antennal sensillum morphology and electrophysiological responses of olfactory receptor neurons in trichoid sensilla of the diamondback moth (Lepidoptera: plutellidae). Fla. Entomol. 99, 146-158. https://doi.org/10.1653/024.099.sp118. Zauli, A., Maurizi, E., Carpaneto, G. M., Hiari, S., Svensson, G. P., Giulio, A., 2016. Antennal fine morphology of the threatened beetle Osmoderma eremita (Coleoptera: Scarabaeidae), revealed by scanning electron microscopy. Microsc. Res. Tech. 79, 178-191. https://doi.org/10.1002/jemt.22618. 